\title{
Que Diotima ens convidi a sopar
}

\author{
Èric Ortega González (Universitat de Barcelona)
}

Anna Pagès, Cenar con Diotima. Filosofía y feminidad.

Barcelona, Herder, 2018, 269 p.

No es pas gaire desgavellat afirmar que, en ocasions, el discurs filosòfic es petrifica com a resultat de certs espectres que surten al seu encontre. De fet, el més que qüestionable progrés en termes de pensament bé pot entendre's com la voluntat de cristal-litzar aquestes aparicions, de sedimentar-les, com l'esforç per desvetllar-les, i, finalment, com l'intent de delimitar-les temàticament -en ocasions, també, metodològicament- en un afany desesperat de donar la talla davant d'un nou assumpte apressant que demana de nosaltres una actitud vigilant i coratjosa. No debades, Hegel deixà escrit en algun lloc que filosofia no era més que el propi temps captat pel pensament.

La qüestió de la feminitat o, altrament dit, l'oportunitat que Diotima ens brinda des del mateix naixement de la filosofia en convidar-nos a sopar és, sens dubte, un d'aquests problemes que han petrificat i, fins i tot, dinamitat el discurs filosòfic des dels seus orígens. I és que fàcilment hom té la sensació que plantejar el problema de la feminitat des de la filosofia suposa immiscir-se en un terreny inhòspit on els antecedents queden en entre dit $i$ tota la tradició que suposadament ens empara, sobtadament, emmudeix. Dit amb poques paraules: a l'ensopegar amb la feminitat des de la filosofia un adquireix la plena consciència -acompanyada, no cal dir-ho, d'un cert aire d'estranyesade què camina a les fosques $i$ sense l'auxili de cap brúixola textual o canònica.
El llibre que ens ocupa en aquesta ressenya, preparat amb cura, per a l'ocasió, amb la bona ploma que caracteritza la professora Anna Pagès, està, si se'm permet dir-ho, àmpliament al nivell del sopar al que ens apostrofa Diotima des dels orígens dels temps. Amb una escriptura, de vegades, un tant preciosista però eficaç, la doctora Pagès tracta, amb paraules seves, «de deconstruir la feminidad como mito» (p. 17) a través d'una molt avinent circularitat interrogativa que es desplegarà tot fent un seguit de solcs sobre el sabonós terrer de la feminitat amb una pregonesa que, si bé variable, sempre es demostrarà pertinent en l'exposició i fecunda en el lector.

Darrera el repertori de preguntes desenvolupat per la nostra autora envers la relació entre feminitat i filosofia tenim que, lluny de poder parlar en termes d'essència o de models $i$ a una gran distància, per tant, d'enfocar aquesta qüestió des d'una perspectiva universal o metafísica, l'assumpte que tenim entre mans ens demana acarar-lo en termes plurals (parlant, d'aquesta manera, de «feminitats» i no de «feminitat» en singular) així com des d'una perspectiva que, tot fent seves algunes de les més encertades categories del pensament neohebraic (relativitat, precarietat, alteritat, etc.), enllacin les contingents condicions de les feminitats amb la mateixa pregunta de què roman, en la filosofia, de la seva condició antropològica. És a dir: situar- 
nos en l'òrbita de la feminitat ens permet plantejar-nos, entre d'altres coses, si la filosofia, com a pràctica humana, pot seguir oferint-nos una genuïna manera de viure o pel contrari està condemnada a ser un reguitzell de sistemes amb més o menys pretensió explicativa però poca o nul.la aspiració formativa.

Diotima, el cèlebre personatge de $E I$ banquet de Plató i responsable de molta de la bilis estesa tant per autors i autores feministes com per no-feministes -bé a favor de la seva l'existència històrica; bé en contra-, serà la presència constant que, en la seva inconstància, vetllarà el pas del lector pacient a través de l'obra que ens ocupa. Poc importa, segons la professora Pagès, si Diotima va ser un personatge històric o una creació literària. El seu interès rau en el fet que la dona de Mantinea, com a signe que és sense interpretar, assenyala, amb tendresa, els buits dels discursos filosòfics masculins, les seves absències, i al fer-ho, posa entre parèntesi el saber constituït de la tradició filosòfica, li planteja dubtes, li retreu amb deferència però amb fermesa... en una paraula: I'importuna.

Diotima, i de la seva mà la feminitat que representa, suposa un «transitar por los conceptos en un tono de incertidumbre rodeada de sombras» (p. 49). Aquesta sembla ser, precisament, la tasca que l'autora ens proposa abordar: dibuixar i desdibuixar les ombres de la incertesa a través de les diverses resignificacions que la dona de Mantinea anirà adquirint en el recorregut que el text, seductorament, ens planteja.

Ja sia com «instancia en tránsito, en contacto con otro universo simbólico, de una lucidez intelectual más afinada» ( $p$. 32), com a «exterioridad marginal» (p. 34), com a «voz al margen que toma distancia de la seriedad filosófica para aligerar la carga de lo conceptual alejada del mundo habitable y reírse de las ocurrencias de Sócrates sobre el amor» (p. 74), com a un mode específic d'enunciació que consisteix en «un saber frágil que puede caer o resquebrajar en cualquier momento; un saber no confrontado a la productividad de lo inmediato fácilmente localizable o comprensible, que se deduce de una relación particular con el tiempo como experiencia de vida» (p. 107), o com a «voz ausente pero no inaudible, encajada en el logos del método socrático al que incordia para despertar de su letárgico acontecer discursivo (...) que apunta hacia otra cosa más allá del sistema filosófico envuelto en un halo metafísicamente sagrado» (p. 269), Diotima s'erigirà, a través de l'apeiroedre que I'Anna Pagès ens perfila de la seva figura, com la salvaguarda d'un mode de fer filosofia que s'enuncia en, per, i a través de la vida, que surt a l'encontre del misteri, que defuig de l'establert masculí, que qüestiona l'universal grec i serveix d'antídot a la prepotència del cànon contemporani «en su posición de autoridad, de inmutable, de jefe de tribu» (p. 185).

Acceptar el convit que Diotima -i la doctora Pagès en nom seu- ens brinda d'acompanyar-la a sopar significa que estar a l'altura del nostre temps implica prendre consciència del lloc que ocupem, alliberar-nos de la gravetat que insuflen tradició i acadèmia, riure-se'n de l'ensopegada de Tales i de les falses dualitats que des de llarg temps han assolat vida i pensament, experiència i saber. Feminitzar la filosofia, de fet, significa això: introduir tot i tothom (homes i dones, transgèneres $i$ genderqueer) en un intent d'anar més enllà de l'anquilosament d'un pensament atrapat una $i$ altra vegada sobre si mateix. Diotima ja ha llançat la invitació; cal només decidir que portarem nosaltres de postres. 